\title{
Using 3D Microscopy to Analyze Experimental Cut Marks on Animal Bones Produced with Different Stone Tools
}

\author{
Erika Moretti ${ }^{1}$, Simona Arrighi ${ }^{1,2}$, Francesco Boschin ${ }^{1,2^{*}}$, Jacopo Crezzini ${ }^{1,2}$, Daniele Aureli ${ }^{1,3}$, and Annamaria Ronchitelli ${ }^{1}$
}

Author Addresses: ${ }^{1}$ Università degli Studi di Siena, Dipartimento di Scienze Fisiche, della Terra e dell'Ambiente, Unità di Ricerca Preistoria e Antropologia, Via Laterina 8, 53100 Siena, Italy. ${ }^{2} \mathrm{CeSQ}$, Centro Studi sul Quaternario ONLUS. Via Nuova dell'Ammazzatoio 7, I - 52037 Sansepolcro (Arezzo), Italy. ${ }^{3}$ Université Paris Ouest Nanterre La Défense, UMR 7041 - ArScAn, Equipe AnTET, boite $n^{\circ} 32$, Maison René Ginouvès (MAE), 21 allée de l'université F-92023 Nanterre Cedex, France.

"Corresponding Author: fboschin@hotmail.com

Received: February 19, 2015

Volume: 6(2):267-275

Published: December 18, 2015

(C) 2015 Society of Ethnobiology

Abstract: This study uses a combination of digital microscopic analysis and experimental archaeology to assess stone tool cut marks on animal bones. We used two un-retouched flint flakes and two burins to inflict cut marks on fresh, boiled, and dry ungulate bones. The experiment produced three series of three engravings on each bone with each of the experimental tools. The first series involved one single stroke; the second, two strokes in the same direction; and the third, multiple strokes using a to-and-fro movement. We analyzed the striations using a Hirox 3D digital microscope (KH-7700) and collected metric and profile data on the morphology of the cut marks. In order to describe the shape of each cross section, we calculated the ratio between the breadth at the top and the breadth at the floor of cut marks. Preliminary results show that both the tool type and the method of creating the cut mark influence the shape of the resulting groove. In our experiment, morphological parameters can be used to differentiate between marks produced using un-retouched flint flakes and those produced using burins. However, neither morphological nor morphometric analysis allows us to identify the mechanical motion used to produce the cuts, nor the state of the bone (fresh, boiled, or dry) at the moment of marking.

Keywords: Taphonomy, Digital microscopy, 3D imaging, Cut marks, Zooarchaeology

\section{Introduction}

3D digital microscopy has many applications in archaeological research, particularly for precise micromorphometric analysis of very small surfaces, enabling measurements in three dimensions. In previous studies, 3D microscopy allowed us to distinguish between grooves inflicted by stone and metal tools (Bello and Soligo 2008; Boschin and Crezzini 2012), as well as characterize the marks produced by ancient tools (Bello et al. 2009). Similarly, 3D microscopic analysis of grooves present on two human teeth from Epigravettian (ca., 17,0000-10,000 years BP) layers of Grotta Paglicci (Southern Italy) enabled the interpretation of tooth picking behaviours aimed at alleviating sore gums (Ricci et al. 2014). In their study of "hatched bricks," a type of brick used in civil and religious monumental architecture during 12th-14th centuries in Northern and Central Italy, Arrighi et al. (2012b) used 3D microscopy of experimental engravings to define parameters that suggested a link between engraving patterns, the tools employed, and the action performed.
The application of 3D technologies has also produced useful data related to engraved Palaeolithic mobiliary art (Bello et al. 2013; Güth 2012; Joordens et al. 2014; Moretti 2014), where research has informed the technical and artistic procedures followed by prehistoric artists. Over the last few years the authors have been carrying out a review of the entire portable art assemblage of Grotta Paglicci (Foggia, Southern Italy) by means of 3D digital microscopy. This 12-meter thick stratigraphic sequence is considered a reference for understanding the evolution of the Upper Palaeolithic in Italy and is more generally a point of reference for the whole of the South-Eastern Mediterranean region (Palma di Cesnola 1993, 2006; Ronchitelli et al. 2014; Wierer 2012). The Grotta Paglicci research program is developing an experimental approach with the following goals:

1) To characterize artistic engravings and butchering marks on bone surfaces with micromorphometric parameters. 
Table 1. Experimentally produced stone tools used to create cut marks.

\begin{tabular}{|c|c|c|c|c|c|c|c|}
\hline $\begin{array}{l}\text { Tool } \\
\text { number }\end{array}$ & $\begin{array}{l}\text { Length } \\
(\mathrm{mm})\end{array}$ & $\begin{array}{l}\text { Width } \\
\text { (mm) }\end{array}$ & $\begin{array}{l}\text { Thickness } \\
(\mathrm{mm})\end{array}$ & Tool type & $\begin{array}{l}\text { Type of } \\
\text { blank }\end{array}$ & $\begin{array}{l}\text { Cutting } \\
\text { edge }\end{array}$ & $\begin{array}{l}\text { Prehensile portion (proximal end of } \\
\text { tool) }\end{array}$ \\
\hline $\begin{array}{l}\text { Tool } 1 \\
\text { (Figure } \\
1 \mathrm{~A})\end{array}$ & 63 & 27 & 17 & $\begin{array}{l}\text { burin on } \\
\text { fracture }\end{array}$ & $\begin{array}{l}\text { Thick flake } \\
\text { cortex } \\
\text { removal } \\
\text { phase }\end{array}$ & $\begin{array}{l}\text { dihedral; } \\
\alpha: 70^{\circ} ; \beta \text { : } \\
90^{\circ}\end{array}$ & $\begin{array}{l}\text { presence of backs (back } A \text {, opposite } \\
\text { side to the functional part: thick- } \\
\text { ness: } 15 \mathrm{~mm} \text {; back } B \text {, adjacent to the } \\
\text { functional part: thickness: } 10 \mathrm{~mm} \text { ) }\end{array}$ \\
\hline $\begin{array}{l}\text { Tool } 2 \\
\text { (Figure } \\
\text { 1B): }\end{array}$ & 59 & 36 & 15 & $\begin{array}{l}\text { burin on } \\
\text { fracture }\end{array}$ & $\begin{array}{l}\text { Thick flake } \\
\text { cortex } \\
\text { removal } \\
\text { phase }\end{array}$ & $\begin{array}{l}\text { dihedral; } \\
\alpha: 70^{\circ} ; \beta \text { : } \\
90^{\circ}\end{array}$ & $\begin{array}{l}\text { presence of backs (back } A \text {, opposite } \\
\text { side to the functional part: thick- } \\
\text { ness: } 15 \mathrm{~mm} \text {; back } B \text {, adjacent to the } \\
\text { functional part: thickness: } 10 \mathrm{~mm} \text { ) }\end{array}$ \\
\hline $\begin{array}{l}\text { Tool } 3 \\
\text { (Figure } \\
1 \mathrm{C})\end{array}$ & 26 & 28 & 7 & $\begin{array}{l}\text { un- } \\
\text { retouched } \\
\text { flint flake }\end{array}$ & $\begin{array}{l}\text { blank: } \\
\text { flake }\end{array}$ & $\begin{array}{l}\text { dihedral; } \\
\alpha: 50^{\circ} ; \beta \text { : } \\
70^{\circ}\end{array}$ & $\begin{array}{l}\text { absence of back on the opposite side } \\
\text { to the functional part; presence of a } \\
\text { back adjacent to the functional part } \\
\text { (thickness of back: } 0.7 \mathrm{~mm} \text { ) }\end{array}$ \\
\hline
\end{tabular}

2) To differentiate engravings produced by different types of lithic tools.

3) To identify the origin of uncertain marks on bones found at Grotta Paglicci (if they are produced with artistic meanings or if they are the result of subsistence activities).

4) To reassess previous evaluations of artistic engravings from Grotta Paglicci that were based on optical microscopy.

The research reported in this paper focuses on the contribution of 3D digital microscopy to identifying the origin of different kinds of grooves on modern animal bones, in order to inform our study of archaeological bones from Grotta Paglicci. We focus specifically on the potential to differentiate between cut marks produced by un-retouched flakes (generally, very sharp and thin) and those produced by burins which are comparatively more robust and oblique. While un-retouched flakes were likely used both for butchering activities and artistic production by ancient populations due to the ease of making them and their superior cutting capabilities (Dewbury and Russel 2007), burins were also hypothesized to be used, among other activities, in the production of prehistoric artistic engravings at Grotta Paglicci (Arrighi et al. 2008; Arrighi et al 2012a).

\section{Materials and Methods}

Taphonomic studies on bone remains have long demonstrated the potential for recognizing micromor- phological parameters useful for identifying the origin of cut marks (e.g., Greenfield 1999; Potts and Shipman 1981). The improved imaging technology provided by 3D digital microscopy allows the capture of a 3D image of a cut mark along its entire length. In addition, analyzed surfaces do not need to be specially prepared, and digital representations are obtained in a few minutes. This approach also allows visualization of the mark's cross sections and collection of morphometric data that can be analysed statistically. In previous studies 3D morphology of marks (particularly the distinction between " $\mathrm{V}$ " shaped marks and " \_/" shaped marks) was analyzed using 2D imagery (e.g., Domínguez-Rodrigo et al. 2009). In our experience, directly observing cross sections of cut marks is not readily feasible using conventional 2D microscopy (both optical and SEM) because diagnostic criteria pertaining to the micromorphology of the cross sections and the slopes and floor of the grooves are difficult to calculate. While an innovative alternative approach using microscopic observations of transversally cut casts or moulds was carried out by Greenfield (1999), this also relied on a 2D image when a $3 \mathrm{D}$ image is better suited to such an analysis.

For the experimental study presented here, we focused on two types of lithic artefacts: burins and un -retouched flakes. Tools were produced by one of the authors (DA) using flint obtained from the Gargano promontory (Apulia, Southern Italy). Burins were produced according to the technical variability of Epigravettian burins found at Grotta Paglicci. The 


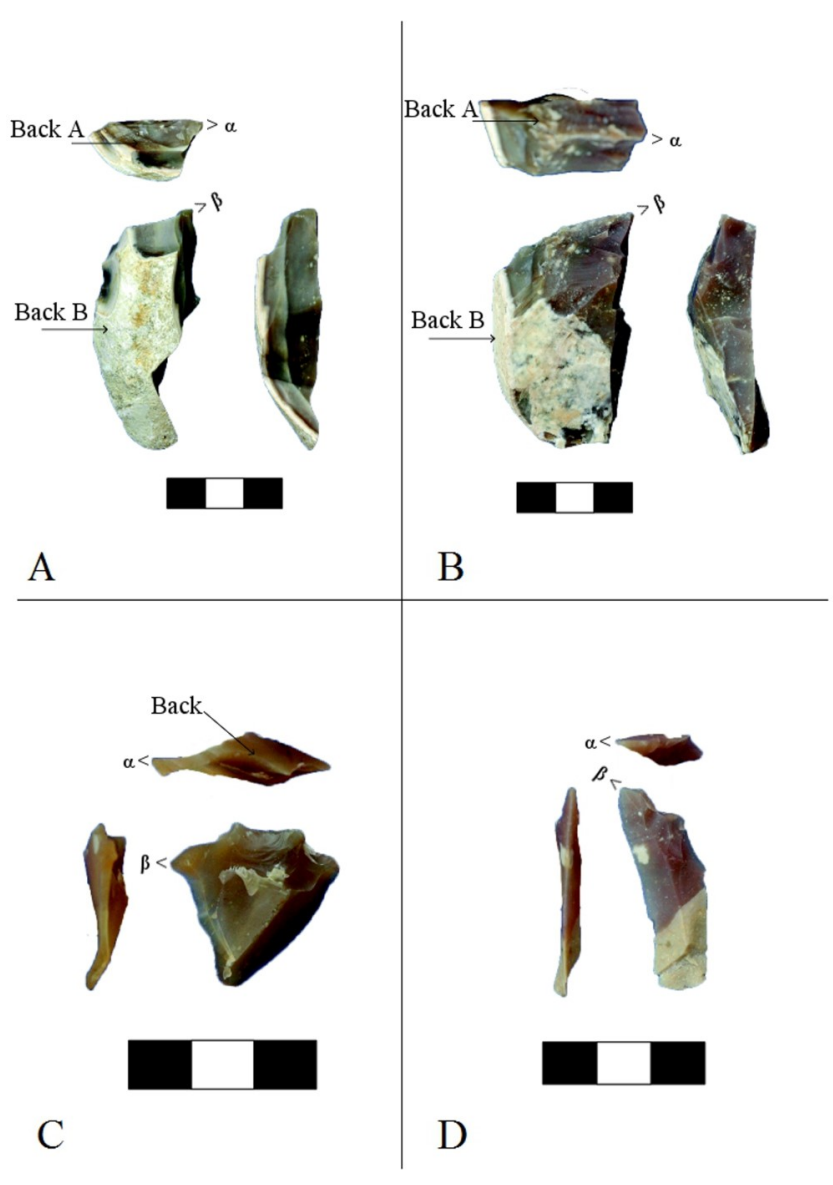

Figure 1. Burins produced for the experiments . $\alpha, \beta$ : angles characterizing the cutting edge. Measurements are reported in Table 1.

following description of experimental tools follows a techno-functional typology (Lepot 1993; Boëda 2001), aimed at understanding the role of the tool's prehensile and functional parts in the production of engravings. Parameters of produced tools are presented in Table 1. In this study, we refer to both engravings and butchery marks as "cut marks." However, we distinguish engravings from butchering marks by the latter being the epiphenomenal by-product of butchering soft tissue (Lyman 1987). In contrast, we define "engravings" as cut marks of prearranged shape, made with a slow and controlled hand movement on a flat surface (as one would see in bone working, as opposed to butchery). We produced engravings on three modern bones: a roe deer (Capreolus capreolus Linnaeus Cervidae) scapula (dry bone), a cattle (Bos taurus Linnaeus Bovidae) innominate (fresh bone), and a cattle scapula (after boiling to remove soft tissues) (Figure 2). The roe deer scapula was collected from a field in north-eastern Italy. The bone surface is well preserved and does not show any kind of weathering. The cattle bones came from an animal that was butchered a few days before this experiment took place. Engravings were produced by the lead author, maintaining control on two parameters: force applied and hand position. The experiment produced three series of three engravings on each bone with each of the experimental tools. The first series involved one single stroke; the second, two strokes in the same direction; and the third, multiple strokes using a to-and-fro movement. We analysed the engravings using a Hirox KH-7700 digital microscope with an MXG-10C body, an OL-140II lens and an AD-10S Directional Lighting Adapter. This instrument allows creation of a 3D image obtained by the composition of several pictures (up to 120) taken at different focal lengths, enabling the bone surfaces to be observed from different points of view. In addition, the cross-section of each cut mark can be viewed along its entire length. Furthermore, areal, linear, and angular measurements of profiles of cross-sections can be obtained (Arrighi and Borgia 2009). Five crosssections were calculated per cut mark for a total of 540 profile measurements. The cross sections were grouped into seven morphological categories, according to Boschin and Crezzini (2012) (see Figure 3).

The breadth at the top (BT) and breadth at the floor $(\mathrm{BF})$ of individual cut marks, as well as the ratio between the breadth at the top and the breadth at the floor (ratio of top to floor [RTF] index) were recorded on each of the 540 cross sections, following Boschin

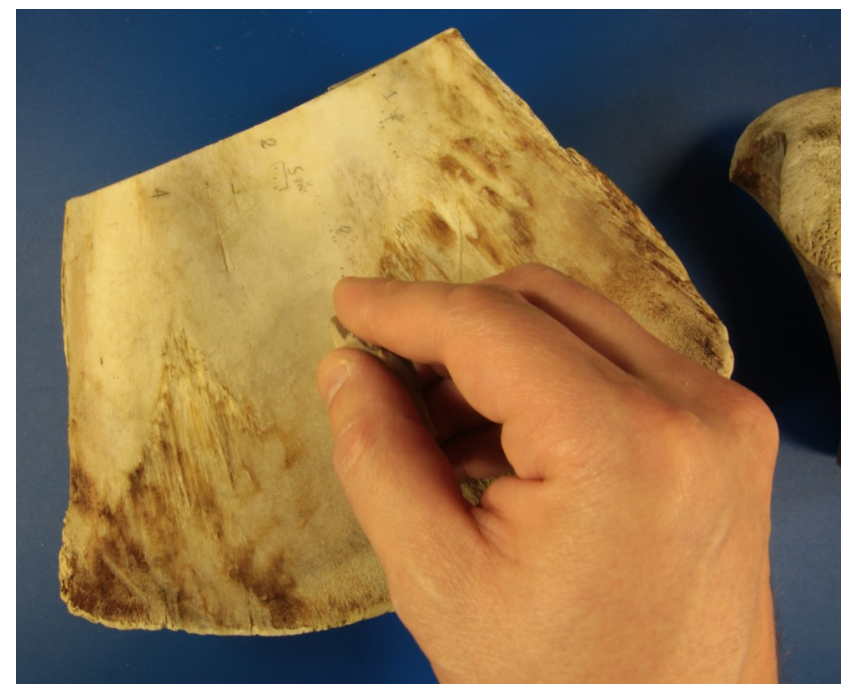

Figure 2. The experimental production of engravings. 
and Crezzini (2012) (Figure 3). The absolute depth of the cut (DC), as defined by Bello and Soligo (2008) was not considered because it is primarily a reflection of the force applied by the operator when producing cut marks.

Micromophological characteristics of these experimentally produced engravings were compared with a sample of archaeologically documented butchery marks (sensu Greenfield 1999) ( $\mathrm{n}=134$ ) identified on Gravettian and Epigravettian faunal remains from Grotta Paglicci (Foggia, Southern Italy), and with epiphenomenal butchery marks produced during modern butchering experiments using unretouched flint flakes ( $\mathrm{n}=93)$. Experimental cut marks in the modern butchering experiments were produced with un-retouched flakes, butchering two

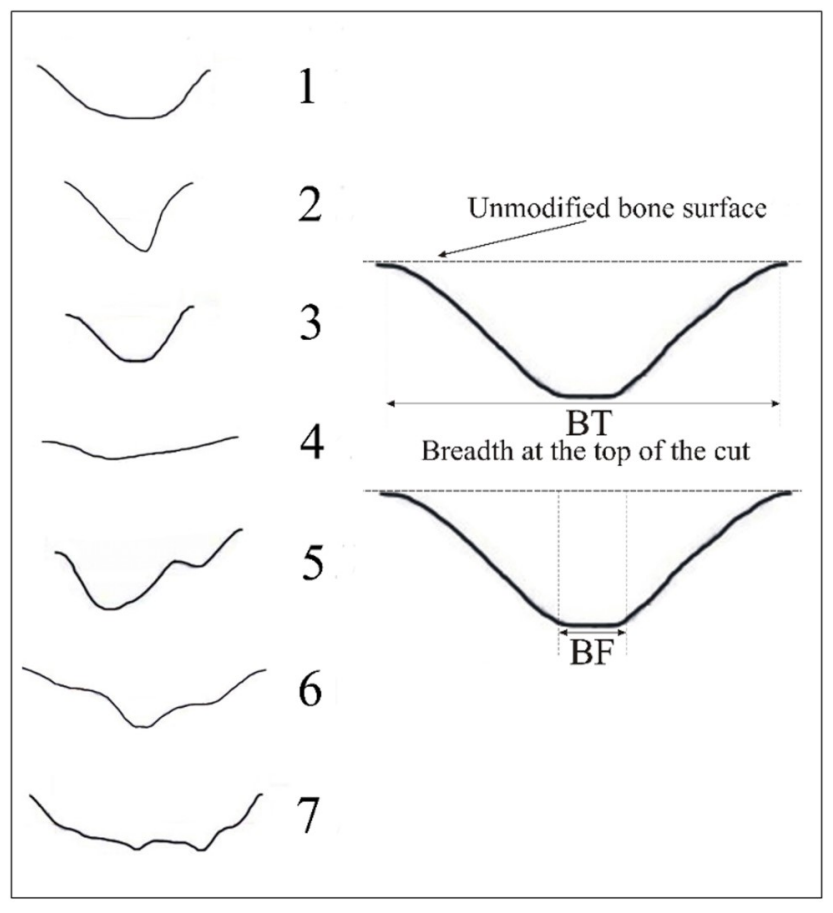

Figure 3. Seven morphological categories and measurements taken on the profiles. Modified from Boschin and Crezzini (2012). 1. profiles with a flat floor; 2. narrow Vshaped regular profiles; 3 . narrow U-shaped regular profiles; 4. broad V-shaped profiles; 5. irregular V- or Ushaped profiles characterised by the presence of one ancillary groove or edge on one side; 6 . irregular $\mathrm{V}$ - or $\mathrm{U}$ shaped profiles characterised by the presence of several ancillary parallel striations, on one or both sides, lateral to the apex of the cut and of uneven length and thickness; 7. profiles with two apexes occurring on the floor of the groove.

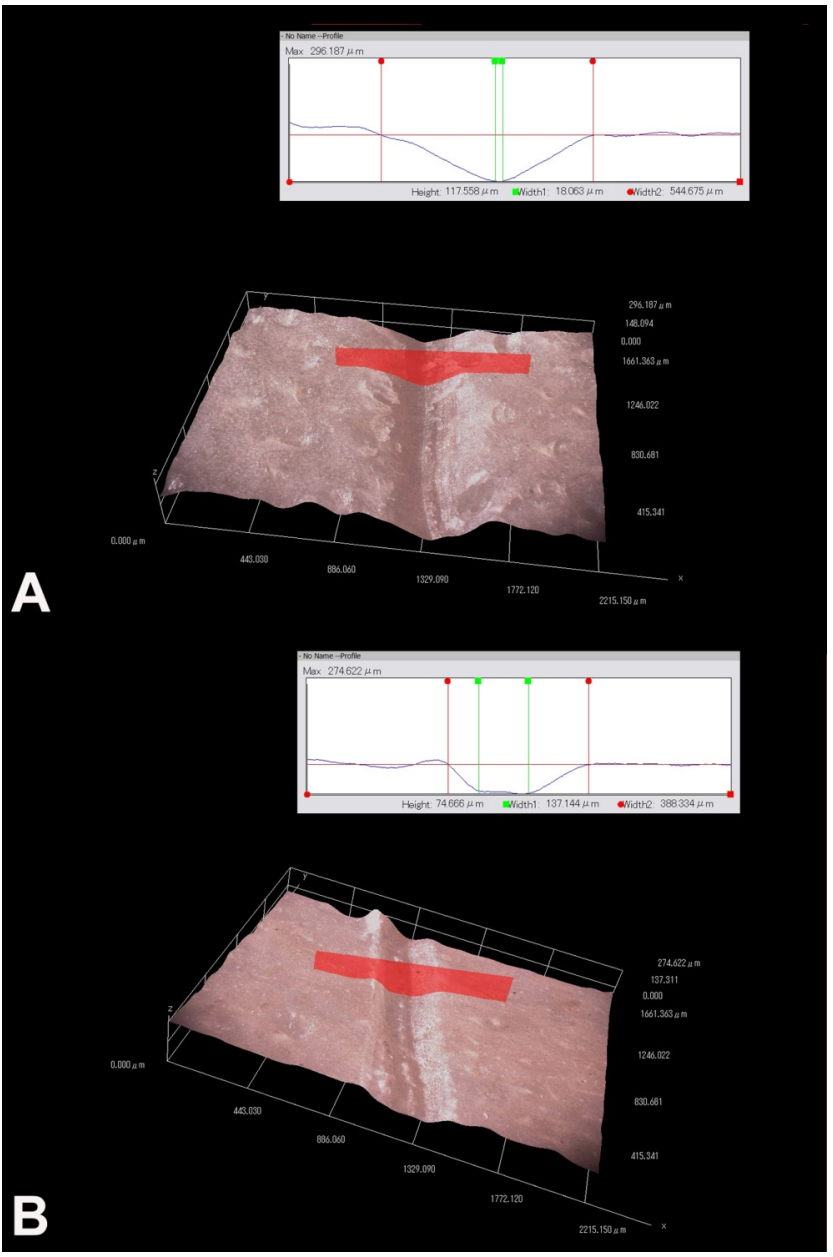

Figure 4. A) Cross-section of an experimental engraving produced with an un-retouched flake. B) Cross-section of an experimental engraving produced with a burin.

fresh cattle autopodia (metapodials and phalanges) and three complete cat carcasses. Cut marks were related to skinning, disarticulation and removal of soft tissues $^{1}$ (Boschin and Crezzini 2012, Crezzini et al. 2014). These comparative archaeological and experimental cut marks will be referred to as "butchering marks" in the following paragraphs and will be examined in relation to the experimentally produced engravings.

\section{Results}

Using high resolution three-dimensional imagery, we first conducted a micromorphological analysis on the entire sample of experimental engravings. This analysis quantified the cross-section morphology of the 540 engravings and placed them into one of seven categories (Figure 3). There is a clear morphological 

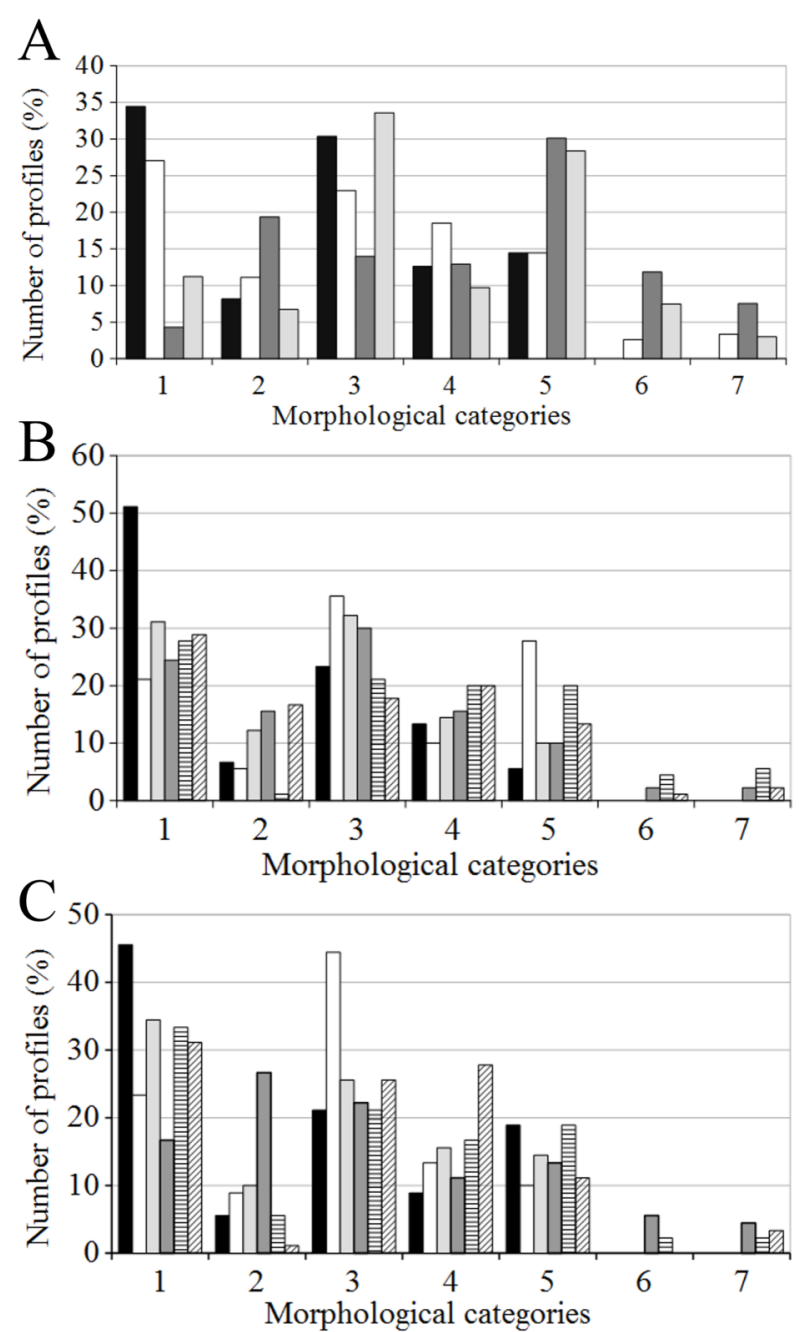

Figure 5. A) Frequency of each morphological category according to the groups; black: experimental engravings (burins, $N=270$ ), white: experimental engravings (unretouched flakes, $\mathrm{N}=270$ ), dark gray: experimental butchering marks ( $N=93)$, light gray: archaeological butchering marks $(\mathrm{N}=134)$. B) Experimental engravings: frequency of each morphological category according to tool and hand movement. Every sample is composed by 90 observations. Black: Burin, single mark; white: burin, to and fro movement; light gray: burin, double unidirectional movement; dark gray: flake, single mark; horizontal hatching: flake, to and fro movement; oblique hatching: flake, double unidirectional movement. C) Experimental engravings: frequency of each morphological category according to tool and bone type. Every sample is composed by 90 observations. Black: Burin, boiled bone; white: burin, fresh bone; light gray: burin, dry bone; dark gray: flake, boiled bone; horizontal hatching: flake, fresh bone; oblique hatching: flake, dry bone. distinction between engravings produced by unretouched flakes which are more irregular and Vshaped (Figure 4A) and engravings produced using burins which have a more U-shaped cross section (Figure 4B). The bulk of engravings produced using sharp un-retouched flakes can be grouped into two morphological categories $(1=27 \% ; 3=22.9 \%$ ), but categories 4 and 5 are also well represented (Figure 5). On the contrary, among engravings produced using burins, category 1 is the most represented (34.4\%), followed by category $3(30.3 \%)$. V-shaped profiles are less represented (categories 2 and 4) and, in general, the distribution of profiles in the seven categories is significantly different between engravings inflicted with un-retouched flakes and those inflicted by burins $\left(\chi^{2}=25.4, p<0.001\right.$; Figure 5A). Notably, burins seem to produce very few engravings with ancillary edges or irregular microstriations within the main groove (category 6) or with two ridges on the floor (category 7) suggesting that these categories may explain why they are infrequently observed.

Butchery marks produced with un-retouched flint flakes during butchering experiments tend to be $\mathrm{V}$ shaped (category 1 counts only for about the $4.3 \%$

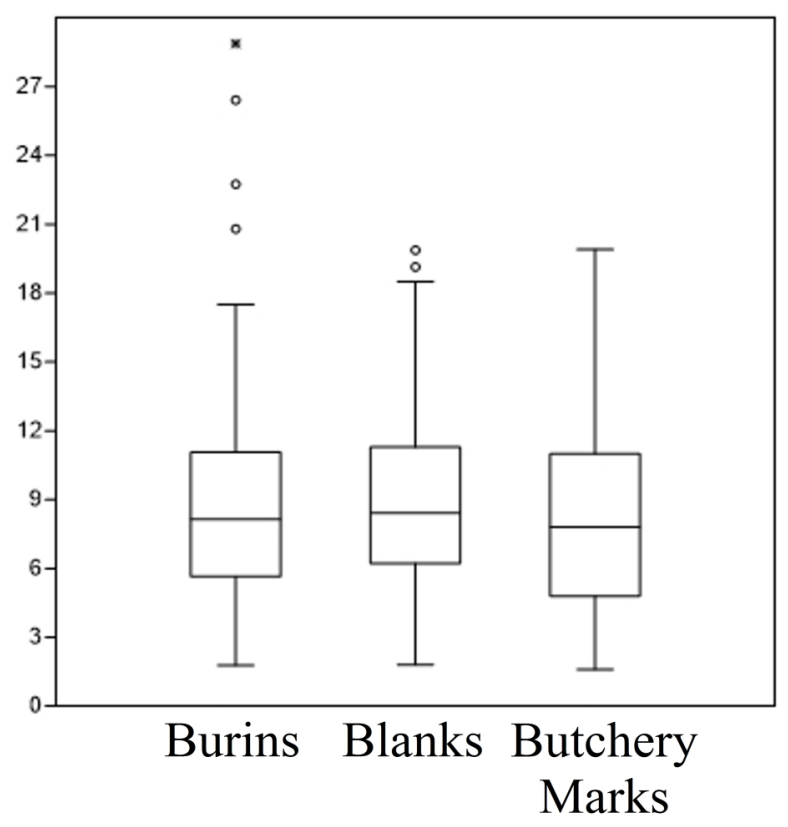

Figure 6. RTF (Ratio between the breadth at the top and the breadth at the floor) of single-stroke engravings (according to tool category) and of butchering marks. Sample size: Burins = 270; Blanks = 270; Butchery Marks $=227$. 

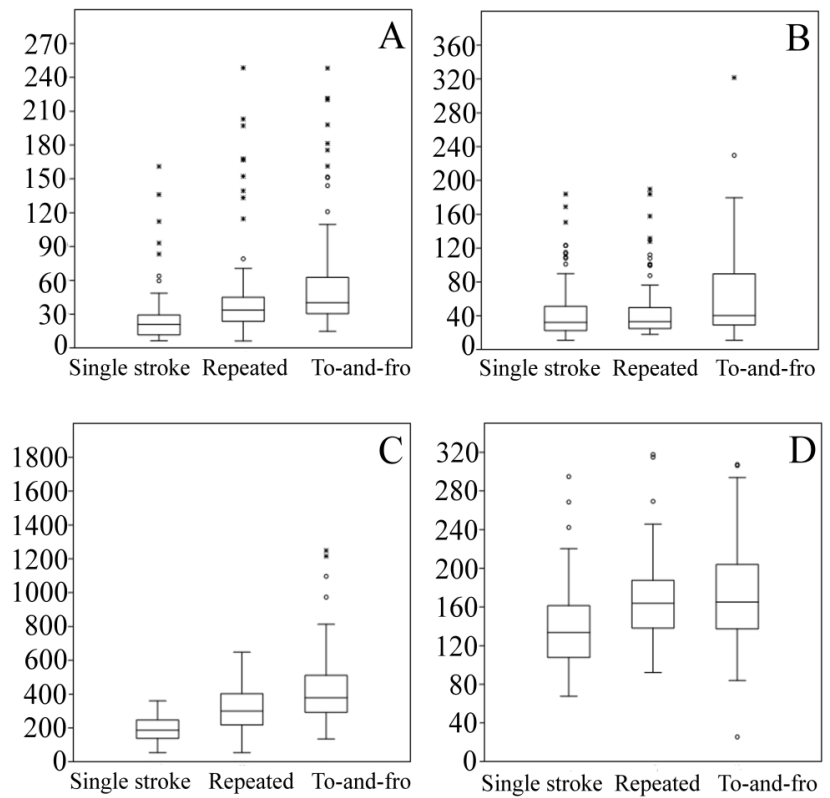

Figure 7. BF (Breadth at the floor) and BT (Breadth at the top) values of engravings according to tool and hand movement. A) BF - Blanks; B) BF - Burins; C) BT - Blanks; D) BT - Buris. Every sample is composed by 90 observations.

and category 3 for the $13.9 \% \mathrm{n}=93$ ) and quite different from the non-butchery-related engravings inflicted with the same kind of tool $\left(\chi^{2}=30.4\right.$, $\mathrm{p}<0.001)$. Category 1 is also under-represented among archaeological butchering marks $(11.2 \%)$.

Differentiating between burins and flakes is difficult if variation in hand movement is considered. U-shaped cross sections tend to increase when flakes are used with multiple hand movements, but decrease when burins are used in the same way. More irregular profiles with internal striations (category 5) seem to increase when all tools type are used inflicting two strokes or with a to-and-fro movement (Figure 5B).

Trends in the micromorphology of engravings remain unclear when comparing fresh bone to dried bone. Differences observed among groups could be related to other parameters, such as the tool used or variability in the movement of the operator (Figure 5C).

Therefore, we further analysed the RTF index values of engravings in order to explore how different tool types, hand movements, and whether bones were fresh or dry influenced the morphology of engravings. Among single-strokes, engravings produced with burins and those produced with flakes show a similar distribution of RTF index values (Figure 6). When subjected to multiple hand movements, the breadth at the top (BT) and bottom (BF) increases (Figure 7). Among burins, cross sections become more U-shaped as indicated by a slight decrease of the RTF values, whilst among blanks this reduction was not observed (Figure 8).

\section{Discussion}

Our experimental results reveal significant morphological differences between engravings produced with burins and engravings produced with un-retouched flakes. Burins composed of two backs, one adjacent (corresponding to a fracture) and one opposite (corresponding to lateral cortex) indicate that the proximal (prehensile) portion of the tool is a key functional element. Morphological characteristics of this 'prehensile' portion of the tool provides more control over movement and in the application of force. Conversely, the two un-retouched flakes do not have thick prehensile portions and accordingly, lacks the force of burins when tools are used by hand.

In addition, the wider edge angles of burins ( $\alpha$ between $70^{\circ}$ and $90^{\circ}$ ) are more oblique than in unretouched flakes ( $\alpha$ between $30^{\circ}$ and $50^{\circ}$ ). Thus the edge of an un-retouched flake could be more fragile and likely to chip when inflicting marks on hard materials, resulting in an irregular shape. These characteristics likely explain the greater variability observed among marks produced with flakes that have not been retouched than those which are characterised by more irregular ridges or internal striations.

It is important to note that the morphology of experimental butchering marks inflicted with unretouched flakes, is measurably different from that of
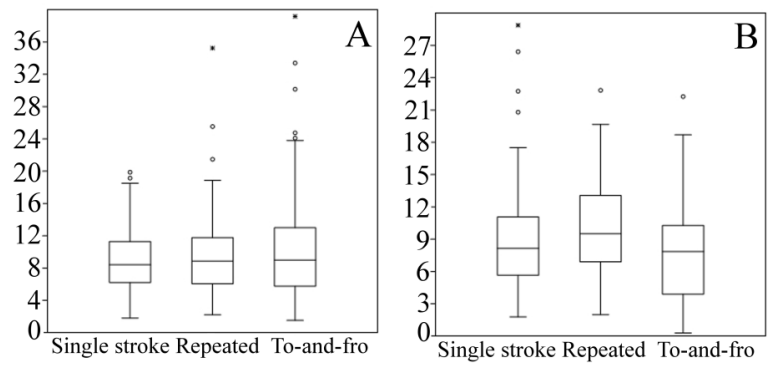

Figure 8. RTF (Ratio between the breadth at the top and the breadth at the floor) of engravings, according to tool and hand movement. A) Blanks; B) Burins. Every sample is composed by 90 observations. 
engravings produced using the same type of tool which were conducted with slow and completely controlled hand movements. On the one hand, production of engravings on the surface of a bone is a goal while butchering marks are a secondary consequence of a cutting action (Egeland 2003; Lyman 1987). On the other hand, different applications of a tool can be chosen making use of particular portions of un-retouched flakes (e.g., a dihedral or an elongated cutting edge) as well as different applications of force, hand position, and movement. Following our goal to differentiate cut marks produced by different types of lithic tools, this study shows that tool types have to be considered in relation to the characteristics of their prehensile and functional elements and not only in relation to their technological categorization (such as "burin" or "un-retouched flake").

Our analysis shows that metrical data on cut marks vary depending on the type of action adopted. For instance, with a to-and-fro movement the breadth of marks increases and, at least among burins, crosssections become more U-shaped. However, clear quantitative differences between profiles of cut marks produced by burins and flakes do not emerge. Thus, absolute measurements (BT and BF) cannot be used to reliably distinguish between them because they can depend on the size of the tool's edge and its penetration into the bone tissue. The distribution of values of the RTF index, which is a function of the shape of the tool's edge, is quite similar with an analogous mean ( $t$ test, experimental engravings, burins vs. flakes: $t=$ $-1.19, p=0.23)$.

\section{Conclusions}

This paper presents our first attempt at using 3D microscopy to characterize and examine variability in marks produced by specific lithic tool types on a range of bone surfaces. Our preliminary research supports 3D microscopy as a promising method to analyze and quantify the micromorphology of butchery marks and engravings. Our results suggest that most marks have U-shaped cross sections (morphological categories 1 and 3) and lack more complex shapes (categories 5, 6, 7) and therefore can be considered to be produced by robust functional edges of tools (such as burins). Conversely, profiles characterized by a narrow floor, including the presence of engravings with two ridges on the floor or irregular striations or internal ridges, suggests the use of narrower or more fragile functional elements of tools (for instance, the edges of un-retouched flakes). However, neither morphological nor morphometric analysis allows us to identify the hand motion used to produce the marks, nor the state of the bone (fresh or dry) at the time of marking.

We observe that un-retouched flakes produce morphologically different cut marks depending on the activity: prearranged cuts created by controlled, slow, and regular hand movements on flat, clean bone surfaces (such as used for bone working) differed from cuts produced during butchering activities. This evidence is relevant in developing future experimental protocols in the study of tool marks and other human caused traces on bones. While our results remain preliminary, they show a distinction between engravings produced with different tool types, although they also show that such morphological observations cannot be made in the absence of other contextual evidence.

In future research, we plan to apply this method to archaeological materials from Grotta Paglicci, where recent research has demonstrated a significant micromorphometric difference between artistic Epigravettian engravings and butchering marks (Moretti 2014). The preliminary results presented in this paper have helped us improve our experimental protocol for future research. The refined protocol will (1) include the use of other types of lithic artifacts (i.e. retouched flakes) and (2) maintain greater control of the modern substrate in the experiments by using the same bone elements from the same species observed in the archaeological sample.

\section{Acknowledgements}

We thank the Soprintendenza per i Beni Archeologici della Puglia for supporting research at Grotta Paglicci. We are also grateful to the editors of this special issue for editing and improving the original manuscript.

\section{Declarations}

Permissions: None declared.

Sources of Funding: None declared.

Conflicts of Interest: None declared.

\section{References Cited}

Arrighi, S., V. Borgia, F. d'Errico, and A. Ronchitelli. 2008. I ciottoli decorati di Paglicci: raffigurazioni e utilizzo. Rivista di Scienze Preistoriche 58:39-58.

Arrighi, S. and V. Borgia. 2009. Surface Modifications of Flint Tools and Their Functional Meaning. 
Materials and Manufacturing Processes 24:922-927. Doi:10.1080/10426910902987150.

Arrighi, S., V. Borgia, F. d'Errico, S. Ricci, and A. Ronchitelli. 2012a. Manifestazioni d'arte inedite e analisi tecnologica dell'arte mobiliare di Grotta Paglicci (Rignano Garganico - Foggia). Preistoria Alpina 46:49-58.

Arrighi, S., I. Cacciari, F. Gabbrielli, M. Giamello, A. Mencaglia, and S. Siano. 2012b. I mattoni graffiati della Fonte Nuova, Siena. Analisi delle superfici. Atti del VII Congresso Nazionale di Archeometria, Modena 22-24 Febbraio 2012, pp. 674-689. Pàtron editore, Bologna.

Bello, S. and C. Soligo. 2008. A New Method for the Quantitative Analysis of Cutmark Micromorphology. Journal of Archaeological Science 35:1452-1552. Doi: 10.1016/j.jas.2007.10.018.

Bello, S., S. A. Parfitt, and C. Stringer. 2009. Quantitative Micromorphological Analyses of Cut Marks Produced by Ancient and Modern Handaxes. Journal of Archaeological Science 36:1869-1880. Doi: 10.1016/ j.jas.2009.04.014.

Bello, S. M., I. De Groote, and G. Delbarre. 2013. Application of 3-Dimensional Microscopy and Micro-CT Scanning to the Analysis of Magdalenian Portable Art on Bone and Antler. Journal of Archaeological Science 40:2464-2476. Doi: 10.1016/ j.jas.2012.12.016.

Boëda, É. 2001. Détermination des unités technofunctionelles de pièces bifaciales provenant de la couche acheuléenne C'3 base du site de Barbas I. In Les Industries à Outils Bifaciaux du Paléolithique Moyen $d^{\prime}$ Europe Occidentale, edited by D. Cliquet, pp. 51-75. Actes de la Table Ronde Internationale, Caen, 14-15 octobre 1999, Eraul 98, Liége.

Boschin, F., and J. Crezzini. 2012. Morphometrical Analysis on Cut Marks Using a 3D Digital Microscope. International Journal of Osteoarchaeology 22:549562. Doi: 10.1002/oa.1272.

Crezzini, J., F. Boschin, U. Wierer, and P. Boscato. 2014. Wild Cats and Cut Marks: Exploitation of Felis silvestris in the Mesolithic of Galgenbühel/Dos de la Forca (South Tyrol, Italy). Quaternary International 330:52-60. Doi: 10.1016/j.quaint.2013.12.056.

Dewbury, A. G. and N. Russel. 2007. Relative Frequency of Butchering Cutmarks Produced by
Obsidian and Flint: An Experimental Approach. Journal of Archaeological Science 34:354-357. Doi:10.1016/j.jas.2006.05.009.

Domínguez-Rodrigo, M., S. de Juana, A.B. Galán, and M. Rodríguez. 2009. A New Protocol to Differentiate Trampling Marks from Butchery Cut Marks. Journal of Archaeological Science 36:2643-2654. Doi:10.1016/j.jas.2009.07.017.

Egeland, C. P. 2003. Carcass Processing Intensity and Cutmark Creation: An Experimental Approach. Plains Anthropologist 48:39-51.

Greenfield, H. J. 1999. The Origins of Metallurgy: Distinguishing Stone from Metal Cut-Marks on Bones from Archaeological Sites. Journal of Archaeological Science 26:797-808.

Güth, A. 2012. Using 3D Scanning in the Investigation of Upper Palaeolithic Engravings: First Results of a Pilot Study. Journal of Archaeological Science 39:3105-3114. Doi:10.1016/j.jas.2012.04.029.

Joordens, J. C. A., F. d'Errico, F. P. Wesselingh, S. Munro, J. de Vos, J. Wallinga, C. Ankjærgaard, T. Reimann, J. R. Wijbrans, K. F. Kuiper, H. J.

Mücher, H. Coqueugniot, V. Prié, I. Joosten, B. van Os, A. S. Schulp, M. Panuel, V. van der Haas, W.

Lustenhouwer, J. J. G. Reijmer, and W. Roebroeks. 2014. Homo erectus at Trinil on Java Used Shells for Tool Production and Engraving. Nature 518:228231.

Lepot, M. 1993. Approche techno fonctionnelle de l'outillage lithique moustérien: essai de classification des parties actives en terme d'efficacité technique. Master thesis, Université Paris X Nanterre, France.

Lyman, R. L. 1987. Archaeofaunas and Butchery Studies: A Taphonomic Perspective. Advances in Archaeological Method and Theory 10:249-337

Moretti, E. 2014. Il Contributo della Nuova Tecnologia 3D Hirox nello Studio dell'arte Mobiliare di Grotta Paglicci (Rignano Garganico, Foggia). Integrazione dell'analisi stilisitica e tecnica su due opere dell'Epigravettiano evoluto. Tesi di Laurea Magistrale inedita, Dipartimento di scienze Fisiche, della terra e dell'ambiente, Università degli Studi di Siena, Siena, Italy.

Palma, di Cesnola A. 1993. Il Paleolitico Superiore in Italia, introduzione allo studio. Garlatti \& Razzai Editore, Firenze. 
Palma di Cesnola, A. 2006. L'Aurignacien et le Gravettien Ancien de la Grotte Paglicci au Mont Gargano. L'Anthropologie 110:355-370.

Potts, R. and P. Shipman 1981. Cutmarks Made by Stone Tools on Bones from Olduvai Gorge, Tanzania. Nature 291:577-580.

Ricci, S., G. Capecchi, F. Boschin, S. Arrighi, A. Ronchtelli, and S. Condemi. 2014. Toothpick Use Among Epigravettian Humans from Grotta Paglicci (Italy). International Journal of Osteoarchaeology In press. Doi: $10.2002 /$ oa.2420.

Ronchitelli, A., S. Mugnaini, S. Arrighi, A. Atrei, G. Capecchi, M. Giamello, L. Longo, N. Marchettini, C. Viti, and A. Moroni. 2014. When Technology Joins Symbolic Behaviour: The Gravettian Burials at Grotta Paglicci (Rignano Garganico e Foggia e Southern Italy). Quaternary International, 359-360:423441 Doi: 10.1016/j.quaint.2014.08.038.

Wierer, U. 2012. Variability and Standardization: The Early Gravettian Lithic Complex of Grotta Paglicci, Southern Italy. Quaternary International 288:215-238. Doi: 10.1016/j.quaint.2012.04.043.

\section{Notes}

${ }^{1}$ Slicing cut marks on spongy bones (epiphyses, tarsal and carpal bones, vertebral bodies) were not included in order to avoid striations whose characteristics may have been dictated by the softness of the bone surface rather than the nature of the cut.

\section{Biosketches}

Erika Moretti graduated at the University of Siena where she produced a thesis on paleolithic portable art objects.

Simona Arrighi is collaborator of the University of Siena studying paleolithic art and use-wear on lithic tools. She is also developing new protocols for the application of 3D microscopy in zooarchaeology.

Francesco Boschin is a zooarchaeologist focusing on prehistoric Italy. He is also developing new protocols for the application of microtomography scans and 3D microscopy in zooarchaeology.

Jacopo Crezzini is a zooarchaeologist focusing on prehistoric Italy. He is also developing new protocols for the application of 3D microscopy in zooarchaeology.

Daniele Aureli is focusing his research interests on the study of lower and middle paleolithic lithic artifacts. He is also carrying out fieldwork on lower-middle paleolithic sites from Italy.

Annamaria Ronchitelli is a Professor at the University of Siena, a paleoanthropologist, and a prehistoric archaeologist working on Italian paleolithic sites. 